\title{
Laws and Policies on Sustainable Development of China's Small Hydropower
}

\author{
Wang Tao ${ }^{1}$, Sun Rong ${ }^{2} \&$ Luo Guoliang ${ }^{3}$ \\ ${ }^{1}$ State Grid Company Weifang Power Supply Company, China \\ ${ }^{2}$ State Grid Corporation 95598 Customer Service Center, China \\ ${ }^{3}$ School of Economics and Management, North China Electric Power University, China \\ Correspondence: Luo Guoliang, School of Economics and Management, North China Electric Power University, \\ 102206, China. E-mail: lg1365365@126.com
}

Received: September 8, 2015

Accepted: October 29, 2015 Online Published: November 20, 2015

doi:10.5539/ass.v11n27p235

URL: http://dx.doi.org/10.5539/ass.v11n27p235

\begin{abstract}
China boasts fairly plentiful water energy in its rural areas, ranking No. 1 in the world. China has made great social, economic and ecological achievements in small hydropower (SHP) development. But SHP development in the rural areas is still confronting unavoidable realistic contradictions: the absence of nationwide laws and compensation institutions and the ambiguity in supervision responsibility. The paper proposes pertinent countermeasures against major problems in laws and policies for China's SHP development.
\end{abstract}

Keywords: small hydropower, rural water energy resource, property rights, laws

\section{Introduction}

Property rights theories opened up a field of research in relation to institutions, actors' strategies and (social or political) processes of resource management. Thus, institutional economics considers property and use rights as key steering factors. Coase (1960) assumes that the internalization of external effects can only be achieved through individual bargaining with the precise definition of use and property rights. Bromley (1991) stressed that "it is essential to understand that property is not an object such as land, but rather is a right to a benefit stream that is only as secure as the duty of all others to respect the conditions that protect that stream."

Property rights $(\mathrm{PR})$ to natural resources with similar characteristics are referred to as a property-rights regime or system. The classification of these regimes is based on different criteria which include title to property, the organization of exclusion, access control and decision-making processes within the regime. Bromley (1992) formulated the distinction between four classical types of regimes: no property, common property, state property and private property. There is no theoretical or empirical justification for the belief that the private property system per se is better than the other PR systems when it comes to the prevention of the overuse of resources; free access is the only regime that is unanimously condemned in this respect.

In accordance with the Constitution and relevant laws of China, in addition to land, most natural resources are state-owned in China, and the country has the ownership of them. In accordance with the Water Law currently in effect, water resources are owned by the state, and the exploitation right for state-owned water resources must be obtained through competitive means. The key and origin of ushering market competition into water energy development is the establishment of water energy exploitation and utilization right in accordance with laws. As the owner of water resources, the state can conduct both positive rights including possession, utilization, profiting and disposal, and negative rights, i.e. eliminating all illicit infringements. In practice, the state authorizes the rights of water resources exploitation and utilization management to ministries of the Central Government and local governments. However, due to the variations in benefits of the Central Government and its representatives at all levels, and the opportunistic conducts of these representatives, severe government failure takes place in the authorization process.

In order to analysis on the restrictions to China's small hydropower (SHP) development, the paper described an analysis framework as follows from the institutional perspective (See Figure 1). In Section I, the paper introduces the achievements of China's SHP and challenges the industry is confronting. In Section II, laws and defects on hydropower resources development and use in rural areas are analyzed. In Section III, institutional 
problems in the management and supervision of rural hydropower resources are demonstrated. Section IV describes the policy defects on the Feed-in Tariff (FIT) of SHP. Section V elaborates the countermeasures on the sustainable development of China's hydropower. And, the last part made the conclusions.

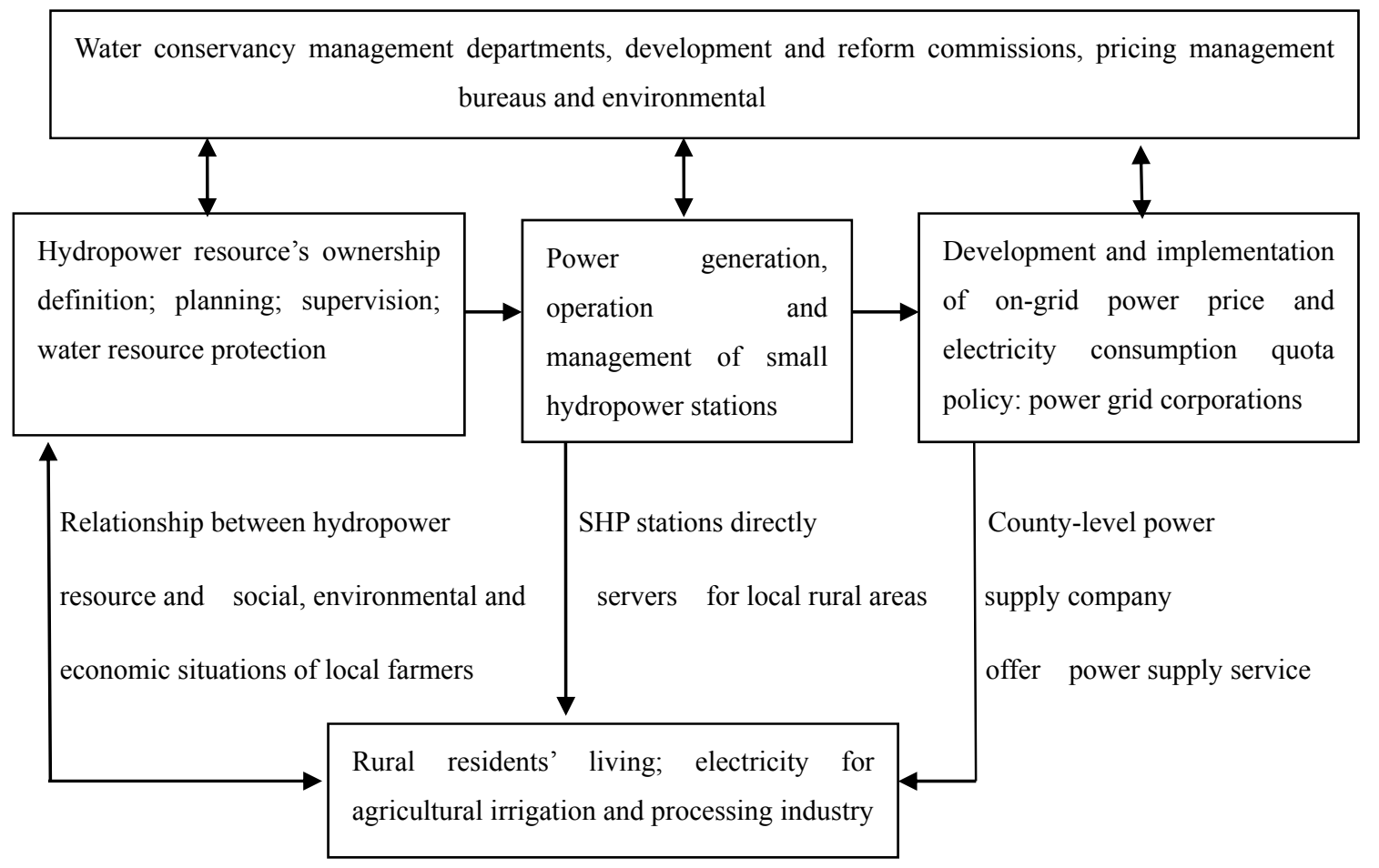

Figure 1. Small hydropower (SHP) development framework in China

\section{Achievements and Challenges of China's SHP}

China's SHP resources are affluent, which can be developed to the amount of 128 million $\mathrm{kW}$ with current technology, ranking first in the world. A total of 1,578 of nationwide 2,300-plus counties have set up SHP stations (Chen, 2009). Most SHP stations are distributed in the poverty-stricken mountainous areas in Western China. By the end of 2010, the exploitable SHP resource gross in Western China is 79.529 million kW, accounting for $62.1 \%$ of total exploitable hydropower resources in rural China.

At the initial period, SHP stations, with installed capacity of $50,000 \mathrm{~kW}$ or below and consisting of hydropower stations themselves and supporting grids, were mainly built and managed by local governments (counties, towns, townships) and farmers to serve for rural and countywide social and economic development.

In early 1980s, Chinese government proposed to boost electrification mainly powered by SHP in rural areas with affluent water resources. The State Council decided to build 600 primary rural hydropower electrification counties in three steps, i.e., the $7^{\text {th }}(1985-1990), 8^{\text {th }}(1990-1995)$ and $9^{\text {th }}(1991-1995)$ five-year plan periods. By the end of 2000, a total of 653 primary rural hydropower electrification counties had been set up. These counties had doubled the GDPs, financial revenues, rural per capita net income and electricity consumption within five years and redoubled within ten years. SHP has become a powerful support to the economy development of poverty-stricken rural areas and counties, an important source of local financial income and an effective channel for farmers to become rich. After20-year hard work, the total installed capacity of SHP had increased 16.50 million $\mathrm{kW}$ and reached 23.5 million $\mathrm{kW}$ at the end of 1999 . The annual average installed capacity put into operation hit $820 \mathrm{MW}$, nearly satisfying the local power demands. SHP kindles the rural areas of China.

Since 2000, Chinese government has paid more attention to the function of SHP stations in rural economy and society, and stressed on great efforts in SHP, rural electrification and the program of Substituting SHP for Fuel. With the large-scale renovation of rural hydropower grid and the strategic restructure of rural hydropower assets, SHP entered the stage of mass production, promoting the water energy resource management and planning.

Legal exploitation and supervision of SHP received greater concern. Continuous progress of economic institution 
reform and inflow of social funds to SHP brought enormous changes to the development situation of SHP.

Upon the access into the $21^{\text {st }}$ century, the CPC Central Committee and the State Council strengthened policy support to rural electrification, which is believed an important condition for agricultural and rural modernization. During the $10^{\text {th }}$ Five-year Plan period (2001-2005), a total of 409 rural hydropower electrification counties, $80 \%$ of them in former revolutionary base regions, regions inhabited by ethnic groups, border regions and poverty-stricken regions, were completed. And nearly 10,000 middle and small rivers were harnessed. The five-year-long electrification completed 115.1billion investment, increased 10.6 million $\mathrm{kW}$ rural hydropower installed capacity, realized per capita annual electricity consumption of $64 \mathrm{kWh}$, up $76.65 \%$ than that in 2000 and 10 percentage points higher than the national average growth. The annual average GDP growth of 409 counties achieved 15\%, 1.7 times of the national average. To meet the economic and social development demand in rural areas, the rural hydropower electrification for 400 counties at a higher standard was initiated in 2006. Over the past three years, the project proceeded smoothly and saw completed investment accumulation of 12.5 billion RMB, 397 completed projects and newly installed capacity of 1260MW.

With the policy incentives and electrification county construction, hydropower developed dramatically. By the end of 2011, a total of 45,000 hydropower stations had been set up with total installed capacity of $62000 \mathrm{MW}$, an increase of 38, $500 \mathrm{MW}$ comparing to that in 2000 with annual increase above 3500MW. In 2011, SHP stations generated 200 billion $\mathrm{kWh}$, accounting for $30 \%$ of China's hydropower.

Between 1978 and 2011, the annual installed capacity growth of SHP is $30 \%$, and of power industry is $11 \%$. The development of SHP and support grid offers power access to $1 / 3$ counties in China and 300 million rural population. Hydropower lightens the whole rural areas of China.

Though small hydropower has big installed capacity, the number of SHP stations are much larger and they are more widely distributed (see Table 1).

Table 1. SHP potential in each province (region or municipality) in China

\begin{tabular}{|c|c|c|c|}
\hline Province/Area & Exploitable capacity(MW) & Annual electricity production (GWh) & Share in China $(\%)$ \\
\hline North China & 2909 & 9799.99 & 1.8 \\
\hline Beijing & 186 & 421 & 0.1 \\
\hline Tianjin & 5 & 20 & 0.0 \\
\hline Hebei & 1206 & 3848.81 & 0.7 \\
\hline Shanxi & 853 & 3380.95 & 0.6 \\
\hline Inner Mongolia & 658 & 2129.23 & 0.4 \\
\hline Northeast China & 5550 & $15,259.43$ & 2.9 \\
\hline Liaoning & 667 & 1889.03 & 0.4 \\
\hline Jilin & 1662 & 5646.75 & 1.1 \\
\hline HeiLongjiang & 3221 & 7723.65 & 1.4 \\
\hline East China & 18,839 & $61,991.88$ & 11.6 \\
\hline Shandong & 64 & 158.6 & 0.0 \\
\hline Jiangsu & 58 & 173 & 0.0 \\
\hline Zhejiang & 4625 & $12,035.85$ & 2.2 \\
\hline Anhui & 1371 & 3952.84 & 0.7 \\
\hline Fujian & 8492 & $30,955.31$ & 5.8 \\
\hline Jiangxi & 4229 & $14,716.28$ & 2.8 \\
\hline Mid-south China & 27,057 & $10,0851.9$ & 18.8 \\
\hline Henan & 875 & $31,09.41$ & 0.6 \\
\hline Hunan & 8001 & $30,410.49$ & 5.7 \\
\hline Hubei & 5455 & $19,680.82$ & 3.7 \\
\hline Guangdong & 6901 & $23,715.26$ & 4.4 \\
\hline Guangxi & 5193 & $21,667.2$ & 4.0 \\
\hline Hainan & 632 & 2268.73 & 0.4 \\
\hline
\end{tabular}




\begin{tabular}{cccc}
\hline South West China & 56,740 & $271,442.65$ & 0.7 \\
Yunnan & 16,330 & $76,906.73$ & 14.4 \\
Guizhou & 7335 & $25,605.99$ & 4.8 \\
Sichuan & 20,698 & $108,312.7$ & 20.2 \\
Chongqing & 3330 & $13,216.61$ & 2.5 \\
Tibet & 9047 & $47,400.59$ & 8.9 \\
North west China & 16,937 & $75,699.04$ & 14.1 \\
Shannxi & 3116 & $12,432.12$ & 2.3 \\
Gansu & 3960 & $19,283.02$ & 3.6 \\
Qinghai & 2341 & $10,727.27$ & 2.0 \\
Ningxia & 13 & 36 & 0.0 \\
Xinjiang & 7507 & $33,220.63$ & 6.2 \\
Total & 128,032 & $53,5044.9$ & 100 \\
\hline
\end{tabular}

As green energy producers, important rural infrastructures and public facilities, SHP stations have realized enormous achievements in releasing local power supply pressure, accelerating rural electrification, eliminating poverty in rural areas, improving livelihood and protecting ecological environment and played an important role in promoting the economic and social development of poverty-stricken areas in rural China. However, SHP development in China is confronting some sharp contradictions.

Lack of a complete drainage area plan for a long time, the swarming hydropower development projects caused problems such as the river cutoff, shortage of drinking water and irrigation water (see Figure 2).

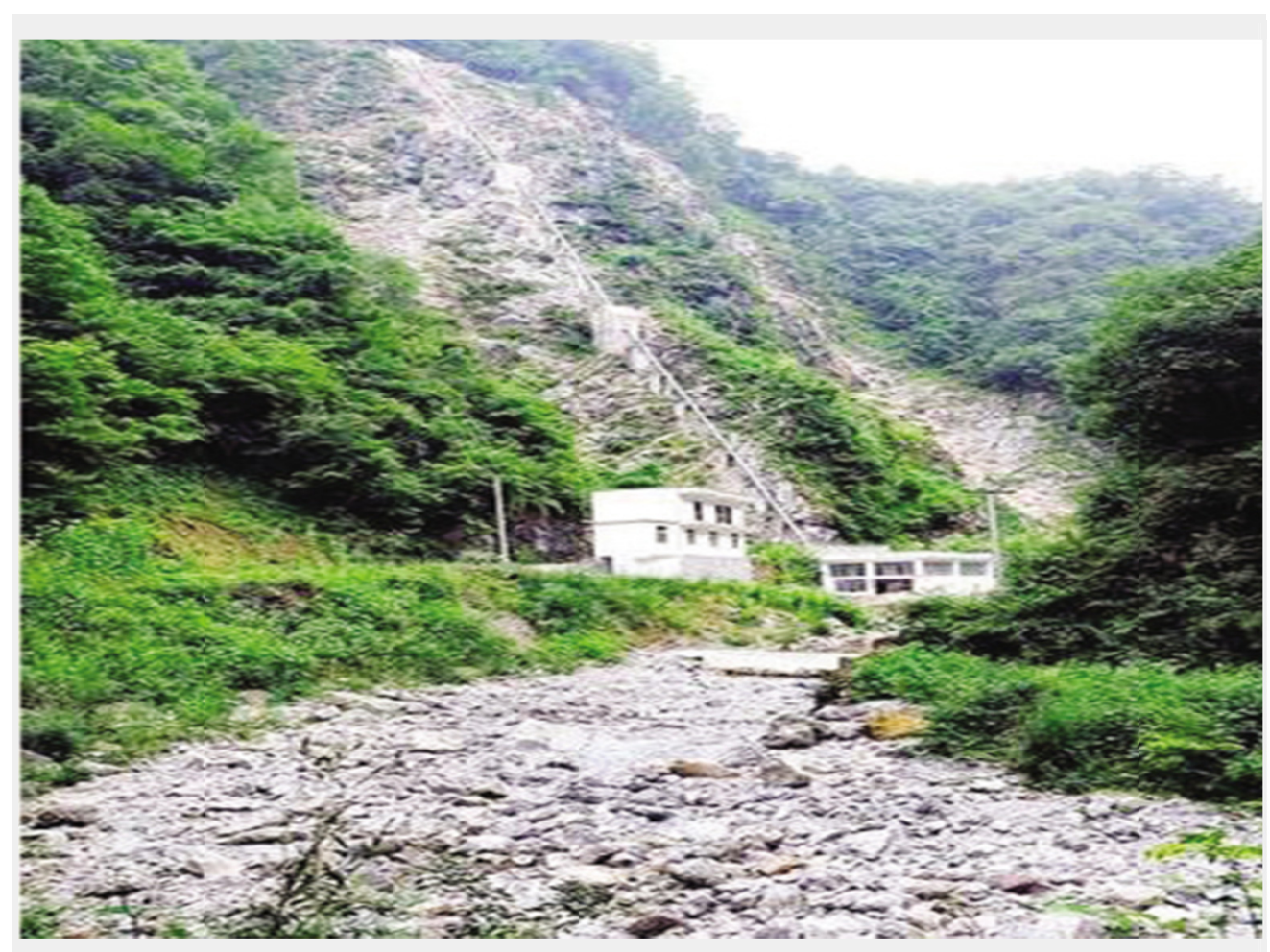

Figure 2. Dried bed of a stream just downstream of the diversion weir of a SHP

Source: Authors' own contribution.

Due to the rapid development of SHP stations in a large scale, some ecological environment problems become increasing serious, mainly in the following aspects:

First, the water flow cutoff. This problem mainly exists in some diversion-type hydropower stations. During the 
dry season, the diversion-type hydropower station is prone to cause the river cutoff and regional low water or high fluctuation of water flow in the lower reaches of the river. Such problems have adverse impact to the ecological system, irrigation, shipping and ecological environment of the upper and lower reaches of the river. The water diversion project across several drainage areas can cause changes of the water flow of the rivers and the hydrological system and impact the production and life water supply and the ecological system on both banks of the rivers.

Second, impact to the biological diversity. Because of construction of the hydropower station, the water quality, water flow and temperature will change and have adverse impact to the protection of fishes and rare animals and plants.

Third, impact to the water quality. Such problem mainly exists in the reservoir-type hydropower stations near the urban areas. After the completion of the reservoir, the water will become deep and the flow rate will slow down. Consequently, the municipal sewage cannot be discharged in time and lead to decline of the water quality of the reservoir.

Fourth, regional vegetation damage and water and soil erosion. During construction of the hydropower station, the disordered waste slag and temporary facilities, in addition to the land occupied by the project, will cause the land waste. At the same time, taking soil will impact the slope and surface soil, damage the vegetation and cause the water and soil erosion, even block the waterway.

\section{Laws and Defects on Hydropower Resources Exploitation and Utilization in Rural Areas}

Utilizing water energy to generate power is one of the important modes to develop water resources. In order to emphasize the power generation function of water resources, water resources for generating power is often called hydropower resources in management. Currently, the state-level legislation on hydropower resource's exploitation and utilization rights has not been established, except for some principles. The Water Law of China is enacted for the purposes of "rationally developing, utilizing, conserving and protecting water resources, preventing and controlling water disasters, bringing about sustainable utilization of water resources, and meeting the need of national economic and social development." The Water Law stipulates "water resources are owned by the State" and "institutions for water intake permit and charged use", fundamentally offering possibility and necessity for hydropower resource exploitation and utilization. The Water Law has a special chapter on Hydropower Exploitation and Utilization, which defines principles and institutions for hydropower exploitation and utilization and doesn't establish hydropower exploitation and utilization right. The Renewable Energy Law defines hydropower is a clean renewable energy, stresses "the state encourages economic subjects of various ownership take part in the exploitation and utilization of renewable energy, and protect the legal benefits of renewable energy." But no specific regulations were made on the development and use right of water energy.

Some regions with affluent water energy have started effective legislation and practice on water energy resource exploitation and utilization. The Management Statutes on Water Energy Resource Exploitation and Utilization developed by Zhejiang and Fujian provinces define "the exploitation of water energy resources should obtain the exploitation and utilization right in accordance with the law, and the exploitation and utilization right for water energy resources should follow the principles of openness, equity and justness, apply the methods of bidding and auction to obtain with payment." Also, the approval, alteration and withdrawal of the exploitation and utilization right for water energy resources are elaborated in the documents.

Water energy, stored in rivers and lakes, is a limited natural resource. SHP is a product of water energy exploitation and utilization through project construction. Water energy development and utilization right is a water-related right established through special administrative permit in order to reasonably develop and utilize water energy resources and realize sustainable utilization. It is a specially approved property right. Only those qualifying development and utilization conditions can apply for hydropower projects. Currently, the paid water energy transfer is carried out in ten provinces. Those intend to exploit and utilize water energy are required to obtain the right through bidding, auction and quotation first. However, existing local statutes only offer fundamental regulations to qualifications and conditions of water energy developers and lack of detailed and concrete regulations.

The state's water energy resources are the object of exploitation and utilization. The exploitation and utilization of water energy consist of diversion and discharge. The water resource developers do not intend to occupy the water itself for a long term. Their occupation is just for the convenience of building facilities and power generation. So, water source or water itself should not be deemed as the object of water energy exploitation and utilization. The exploitation and utilization of water energy resources depend on the water's potential energy and utilize the functional value of water, which are different with the occupation and consumption of water for 
household and industrial uses. The exploitation and utilization of water energy resources, without occupation of the object, is not complete exclusive. It can coexist with water supply, irrigation, sightseeing, navigation and other functions.

\section{Absence of Laws for Exploitation and Utilization of Water Energy Resources in China's Rural Areas}

The exploitation and utilization of water energy resources in China's rural areas are confronting legislative problems as follows. First, the vacancy of overall and professional legislation. The establishment, obtaining, performance, transfer, alteration, loss and termination of the right for exploitation and utilization of water energy resources, actually a property right, should only be defined through laws. But, the state-level special legislative regulations on the right for exploitation and utilization of water energy resources are still absent, resulting in the rather incompleteness of standards, conditions and procedures for the work. Local legal documents promulgated by some provinces, autonomous regions and municipalities, such as Hunan Water Energy Resource Exploitation and Utilization Statute and Jilin Water Energy Resource Exploitation and Utilization Statute, mainly focus on their local actual situation and economic development and fail to meet the demands of standardization and adjustment to the nationwide rural water energy exploitation and utilization. Second, the concept of sustainable development is not deeply carried forward in related legislation. The legislation to water energy resource exploitation and utilization focuses more on boosting local economy through exploiting water energy, lacks of consideration on benefits of migrants and environmental protection, and neglects the basic standpoint of promoting the coordinated development of ecology, society and economy.

The exploitation and utilization of water energy resources in China's rural areas are confronting some problems in practices. First, the free use of water energy leads to severe waste of the important natural resource and public wealth. In recent years, the development and investment of China's SHP resources had great changes. Private capital replaced national capital in SHP development while the concept and institution for paid use of the resource were not established. Thus, grab of rivers and resources frequently happened in rural areas. At the end of $1996,17.3 \%$ of rural SHP stations were state-owned ones, $80.8 \%$ were collective-owned ones, and $1.9 \%$ private or stockholding ones. By the end of $2009,9 \%$ were institutionally owned, $8 \%$ state solely-owned, $55 \%$ state controlled, $11 \%$ collective controlled and $67 \%$ private or stockholding ones (Cheng Xia Lei 2009). Concerning water energy exploitation practice, some private developers don't exploit water energy after obtaining the exploitation and utilization right. Instead, they wait for a good price to sell the right for profit, which not only keeps developers with investment intention and strength away from water energy exploitation but also causes the idleness and waste of water energy resources. Second, the absence of ownership management system. Due to the absence of nationwide rural water energy exploitation and management institution, the governments have no definite regulations on the acquisition modes, acquisition conditions, acquisition procedures, contents, term, alteration and transfer of water energy resource exploitation and utilization right. With the marketization of water energy resource exploitation, the absence of this institution often leads to contradictions and interest disputes related with rural water energy resource exploitation and utilization right. Third, protection of environment and other public benefits are neglected in rural water energy resource exploitation. Some private operators of SHP stations, only seeking for economic benefit, would neither protect the ecological environment nor compensate the local farmer's land loss. Thus, the exploitation and utilization of rural water energy resource development and utilization often conflicts with the functions of irrigation, water supply and tourism and hinders the sustainable development of SHP in rural areas.

\section{Vague Institutions for Rural Water Energy Resource Management and SHP Exploitation Supervision}

Rural water energy resource management mainly covers two aspects. The first aspect is the basic work with resource investigation and evaluation as the core contents. The rural water energy resource development plan shall be jointly developed by water-related administrative authorities (water conservation department/bureau) with corresponding river management jurisdiction and the local development and reform committee of the same level, then demonstrated by relevant departments and experts, and reported to local government for approval. Upon the approval, the energy resource development plan should be stringently carried out. The water administrative authorities shall make regular inspections and evaluation to the performance of the plan. The second aspect is the governmental supervision to the exploitation and utilization of rural water energy resource. Over a long time, hydropower resource management is deemed as the same with and replaced by the hydroelectric management. For example, the Ministry of Water Resources is responsible for guiding the hydroelectric work and organizing the hydropower electrification in rural areas. The National Development and Reform Commission is responsible for the management of petroleum, natural gas, electric power and other energy resources. In actual practice, the concepts of hydropower resource and water resource are not unified. Water resource does not include hydropower resource, which excludes hydropower resource management from 
water resource management.

The Law of Renewable Energy of the People's Republic of China promulgated in 2005 includes hydropower energy into renewable energy and defines the exploitation and use of renewable energy to be managed by energy authorities. But, management responsibilities to hydropower resources are not elaborated.

The legal ambiguity to hydropower resource and its management leads to the inexplicit job division and management responsibilities among governmental developments, which directly causes the delay or lack of hydropower resource planning, ownership management and a series of environmental and social problems.

Before 1998, the construction of SHP stations was under the administration of the provincial planning commission which was responsible for the project approval and the provincial water resources and electric power department which was responsible for the technical instruction. In March 1998, it was decided to cancel the Ministry of Electric Power at the $1^{\text {st }}$ plenary meeting of the $9^{\text {th }}$ NPC and transfer the administrative functions to the rural electric power department of the State Economic and Trade Commission. The rural electric power department is responsible for the administrative law enforcement, administrative and industrial management of the rural electric power industry and steering the rural electrification and countryside grid development and planning. The hydropower development function was transferred to the former State Economic and Trade Commission. In fact, the approval function of the former State Economic and Trade Commission and the State Planning Commission was poorly defined. In 2003, the State Economic and Trade Commission was integrated in the National Development and Reform Commission and the Water Resources Department gradually faded out of the management of hydropower stations. The approval right was limited to the National Development and Reform Commission under the management of the Energy Division.

The absence of supervision on the hydropower station construction and hydropower market from 2003 to 2006 also caused the management vacuum of the water resources. Especially in the project approval stage, there was no regulation institution in place governing the development permit and use right transfer. There were also many other problems such as poorly defined functions and responsibilities of different levels and among different departments, disordered permit issuance authorization and unauthorized approval of local governments. The facts show that the absence of regulation on the SHP stations led to serious results. In 2004, it was found that more than 3,000 SHP stations were developed without the project approval, project design, construction approval and regulation, and $47 \%$ of them were constructed without project approval, $71 \%$ of them without design. These problems led to serious safety challenges. In the same year, the dams of two SHP stations with the total installed capacity of more than $500 \mathrm{~kW}$ failed and killed 27 people.

\section{Policy Defects of SHP FIT}

For a long term, SHP feed-in tariff (FIT) is generally low. In 2011, SHP FIT averaged at $0.28 \mathrm{RMB} / \mathrm{kWh}$, while thermal power FIT at $0.36 \mathrm{RMB} / \mathrm{kWh}$, nuclear power FIT at $0.50 \mathrm{RMB} / \mathrm{kWh}$, wind power FIT at about 0.55 $\mathrm{RMB} / \mathrm{kWh}$ and benchmark price for solar power at $1.09 \mathrm{RMB} / \mathrm{kWh}$. It seemed that SHP stations was lower than prices of power generated with renewable energy sources as well as nuclear power and thermal power FIT. Low FIT restricts the development of SHP stations so that they are incapable of following the state policy for encouraging the development of renewable energy sources.

The pricing and dispatching policies made by the government have not been completely carried out. In 2007, the State Council and the State Electricity Regulatory Commission made the policy to give priority to allocation of hydroelectric power, put all hydroelectric power on grid and FIT on the same grid at the same level. However, the power grid companies didn't completely follow the policy. On the one hand, SHP stations didn't enjoy the priority mentioned above, and the policy on the same price on the same grid was not actually put into practice; on the other hand, the power grid companies didn't build and renovate power grid facilities for generating power with renewable energy sources, resulting in waste of power and water resources. Take Fujian province for example. At the end of 2011, thermal power FIT was $0.4448 \mathrm{RMB} / \mathrm{kWh}$, while the average SHP FIT was 0.2748 $\mathrm{RMB} / \mathrm{kWh}$, with a difference of about $0.17 \mathrm{RMB} / \mathrm{kWh}$; due to low price, SHP stations in Fujian province suffered a total loss of more than five billion RMB, excluding the loss caused by abandoning water resources on purpose.

The preferential policy on maintaining the added-value tax rate for SHP enterprises at $6 \%$ (The tax rate was $17 \%$ prior to 1994) was not put into practice, according to investigation of the National Development and Reform Commission and the Ministry of Water Resources of the People's Republic of China (NDRC 2010). In Hubei province, about one third of SHP enterprises paid 6\% added-value tax, while one third paid 8 to $10 \%$ and one third paid $17 \%$. To some extent, the non-fulfillment of the supporting policy impacted the sustainable development of the SHP enterprises. 


\section{Policies on Sustainable Development of China's SHP}

The analysis to major contradictions in SHP development indicates that the way to guarantee sustainable development of China's SHP is to establish correct and efficient legal institutions and policies.

Rural water energy resource is a public resource. It is quite complicated to define the ownership due to the high information cost. External factors for the rural water energy resource development easily cause the failure of marketization. An effective way to reduce marketization failure is that the government enacts efficient laws, institutions and supporting compensation policies to balance interests of stakeholders. The countermeasures are elaborated as follows.

To establish laws, plans and institutions for the water energy resource exploitation and utilization in China's rural areas.

The primary task in establishing laws and institutions for the water energy resource exploitation and utilization in China's rural areas is to define water energy resource managment responsibilities at the state level. In state-level legislation, water energy resource management shall be included in the unified water resource management; rural water energy resource management departments and their responsibilites shall be defined to form a nationwide water energy resource management system with unified managment and hierachical responsibilities. The nationwide water energy resource management system shall be responsible for water intake, water discharge, water supply, power generation, flood prevention, irrigation and other issues to realize the unified planning, dispatch, operation, supervision and treatment of waer resources. Based on comprehensive resource investigation and evaluation, the rural water energy resource exploitment plan shall define the functions, modes, scale and procedures of water energy exploitment for small and medium rivers. The plan shall be formulated by the water administrative authorities which are mainly responsible for water energy resource's basic investigation, key information collection, and scientific formulation of water energy exploitment plan for small and medium rivers to offer basis for rural water energy's scientific management.

The dispatching and acquisition policies for SHP. SHP's market share and objectives shall be defined and quantified in formulating its development policies. Percentage of SHP in total power generation shall be defined through the country's renewable energy development plan to ensure SHP be distributed and completely purchased with priority.

Tax policies for SHP. Currently, the 6\% value-added tax rate enacted by the country in 1994 is performed for SHP. But it is difficult to implement the policy in practice for quite a few enterprises across the country. The method to improve current tax policies is to pay back the extra tax beyond the $6 \%$ rate immediately or afterwards to guarantee a real tax reduction, and establish a nationwide compensation institution for rural water energy resource exploitation and utilization.

SHP exploitation in China produces external effects in two aspects. On one hand, social and ecological benefits are not presented in rural water energy resource development, and benefits of SHP developers are not compensated. On the other hand, the loss caused by soil erosion, flooded farmland, river damming and water resource waste are not compensated. Thus, it is fairly necessary to establish a reasonable compensation institution for rural water energy resource exploitation and utilization. Other provinces and cities may borrow the successful experience of Zhejiang and Fujian in carrying out the compensation institution.

The compensation institution for rural water energy resource exploitation and utilization consists of subjects, objects, means and objectives of the compensation. The compensation subjects are the goverment and developers for the SHP. The compensation objects include the local government, farmers in the reservoir area, ecological protection and builders. The compensation means mainly include policy, fund, real goods and project compensation. The compensation institution is illustrated as the model in Figure 3 based on different ecological influences of rural water energy resource exploitation and utilization. 


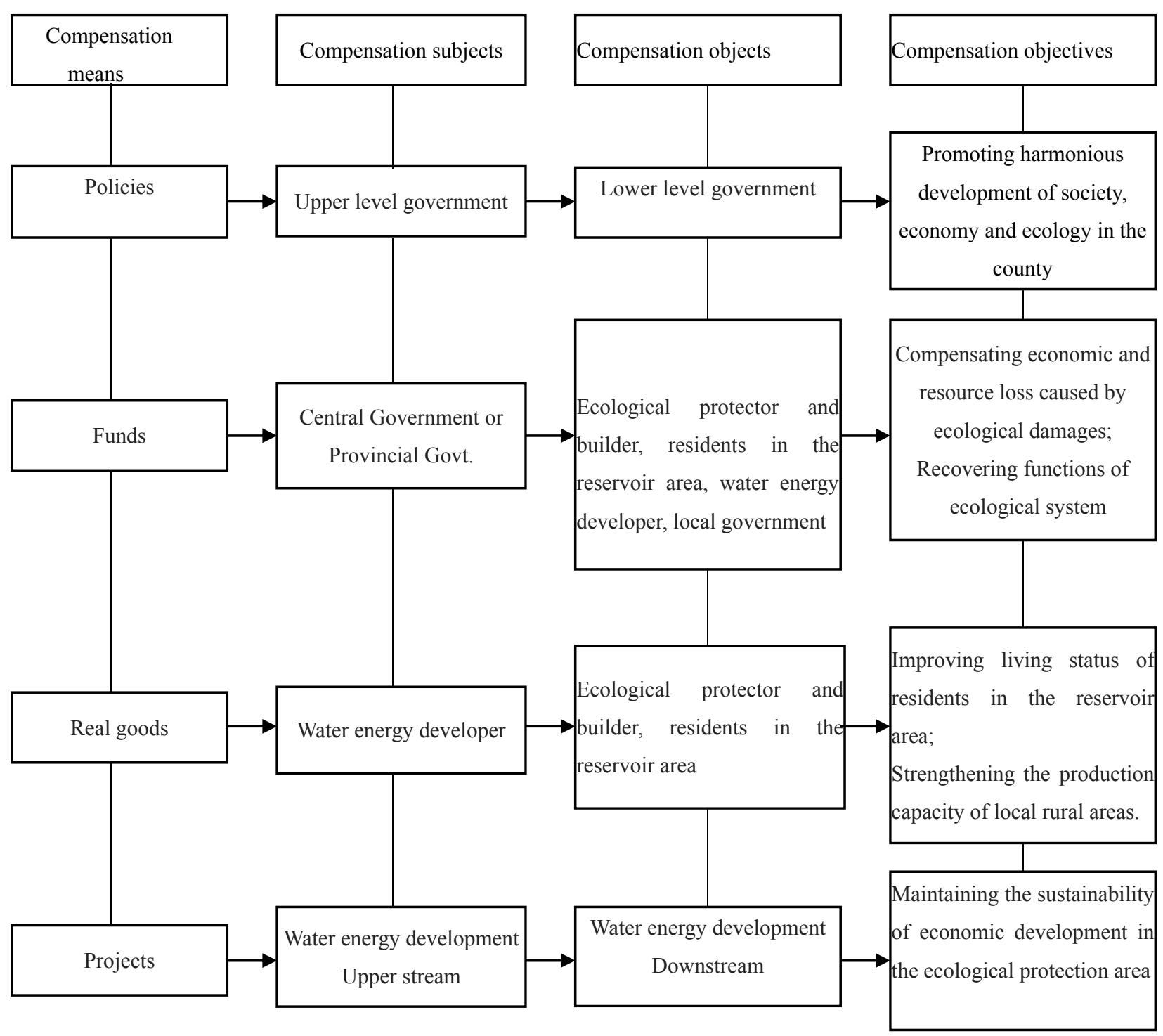

Figure 3. Framework of the compensation institution for rural water energy resource exploitation and utilization

Policy compensation refers to the upper government offers right and opportunity compensation to the local government. The local government may utilize priority and previleges in policy-making within the authorized jurisdiction to develop relevant regional policies based on resource, popultion, economy and environment status. The policies may focus on regional ecological recovery and protection to promote water resource protection and sustainable development of regional economy. For instance, in consideration of the great contribution of Chun'an County, Zhejiang to the construction of Xin'anjiang SHP Station, the Central Government offered loan to Chun'an County to build the 32MW Fengshuling Hydropower Station in 1997 as a compensative project. Chun'an County will have the ownership to the station upon its completion. The profit of the station will be used in reservoir construction and migrant resettlment.

Fund compensation refers to the Central Government, provincial government, water energey developers and beneficiaries will contribute funds to treat and recovery the ecological damages caused by water energy resource development. Fund compensation should be the major means for ecological compensation in water energy resource exploitation. In China, governmental funds play a dominant role in building the ecological compensation mechanism. The Central Government directly or indirectly offers fund support to ecological protectors and builders, residents in reservoir area, key ecological protection area in the basin, rural water energy resource development and protection areas and local governments to release fund shortage, compensate economic and resource loss caused by ecological changes, recover the basin's ecological development ability and improve the ecological system's functions. Currently, fund compensations often include financial payment 
transfer, subsidies, tax rebate and exemption, tax reimbursement and interest discount. Financial payment transfer and subsidies are often performed in practice.

When the reservoir for Dongxi Hydropower Station in Wuyishan City, Fujian was completed and put into operation in 1996, an agreement with local villagers for compensating them $316,400 \mathrm{~kg}$ grain based on the price of that year was reached. By 2008, a total of 320,000 yuan had paid to the villagers for compensation. The Hydropower Station paid 300 million yuan to support migrant resettlement and reservoir area's development.

Real goods compensation refers to water energy resource developers and governments offer material, labor force and land compensation to the production and living elements of ecological protectors and builders, residents in reservoir area and migrants for improving their living status and production capabilities and recovering eclogical protection and construction capabilities. For example, the Beijin SHP Station in Jian'ou, Fujian built docks and bridges to facilitate the traffic of the villages living in the upstream Xudun Town. Some water facilities and channels were also built and repaired to improve agricultural infrastructures when building the reservoir area. Rock protection walls and ramps with total length of $2.3 \mathrm{~km}$ and total investment of 2.6 million yuan were built along the national highway, the banks of the downstream river, the downstream and bank ramp of the tail water. The project guarantees the safety of the reservoir area and downstream watercourse.

Project compensation refers to the compensation subjects' coordination of projects in the upperstream and downstream of the water energy exploitation area to realize ecological compensation. Since the completion of the Xin'anjiang SHP Station in Zhejiang, the local Chun'an County government has gradually strengthened the protection to the water resource of the Qiandao Lake, closed and shut down more than 30 industrial enterprises which produced pollution and paid tens of million tax to the local government each year. In the past ten years, Chun'an County had made direct investment above 1.5 billion yuan in the ecological protection of the Qiandao Lake. The latest data indicate that the water in Xin'anjiang Reservoir qualifies Classification I Water Quality Standard. In 2011, Chun'an County received ecological compensation of 54.82 million yuan.

\section{Conclusions}

China has made eye-catching achievement in SHP development. However, so far, the national law and compensation institutions for rural water energy exploitation and utilization are still a vacancy; the institutions on rural water energy resource management and SHP exploitation supervision are ambiguous; and some incentives to SHP development are not carried out. The practical way for the sustainable development of China's SHP is to establish correct and efficient laws and policies for the exploitation and utilization of rural water energy resources.

\section{References}

Bromley, D. (1991). Environment and Economy: Property Rights and Public Policy. Blackwell, Oxford.

Bromley, D. (1992). Making the Commons Work: Theory, Practice, and Policy. ICS Press, San Francisco.

Chen, L. (2009). Enhancing Rural Water Power Resources Development and Management and Promoting Sustainable Economic and Social Development. China Hydropower \& Electrification, (6), 1-6.

Chen, L. (2012). Rural Hydropower in 2011: New Leap-Forward Development. Small Hydropower, (1), 1-8.

China electric power yearbook editorial board (2003-2013). (2014). China Electric Power Press.

Coase, R. H. (1960). The Problem of Social Cost. Journal of Law and Economics, (3), 1-44. http://dx.doi.org/10.1086/466560

Kucukali, S. (2014). Environmental risk assessment of small hydropower (SHP) plants: a case study for Tefen SHP plant on Filyos River. Energy Sustain Dev, (19), 102-110. http://dx.doi.org/10.1016/j.esd.2013.12.010

Kumar, D., \& Katoch, S. S. (2014). Sustainability indicators for run of the river hydropower projects in hydro rich regions of India. Renew Sustain Energy Rev, (35), 101-108. http://dx.doi.org/10.1016/j.rser.2014.03.048

Kusakana, K. (2014). A survey of innovative technologies increasing the viability of micro-hydropower as a cost effective rural electrification option in South Africa. Renew Sustain Energy Rev, (37), 370-379. http://dx.doi.org/10.1016/j.rser.2014.05.026

Lin, B., \& Wu, Y. (2012). Electricity saving potential of the power generation industry in China. Energy, (40), 307-316. http://dx.doi.org/10.1016/j.energy.2012.01.069

Liu, G., Zeng, Z., Mao, Y., \& Shi, H. (2012). Determination of maximum reclosure time for faulted single transmission line connecting small hydropower system with power grid. Power System Technology, (36), $241-245$. 
Liu, X. M., Zeng, M., \& Han, X. (2015). Small hydropower financing in China: External environment analyses, financing modes and problems with solutions. Renew Sustain Energy Rev, (48), 813-824.

Luo, G.-1., \& Guo, Y.-w. (2013). Rural electrification in China: a policy and institutional analysis. Renew Sustain Energy Rev, (23), 320-329. http://dx.doi.org/10.1016/j.rser.2013.02.040

Ming, Z., Song, X., Mingjuan, M., \& Xiaoli, Z. (2013). New energy bases and sustainable development in China: a review. Renew Sustain Energy Rev, (20), 169-185. http://dx.doi.org/10.1016/j.rser.2012.11.067

Pang, M. Y., Zhang, L. X., \& Ulgiati, S. (2015). Ecological impacts of small hydropower in China: Insights from an emergy analysis of a case plant. Energy Policy, (76), 112-122. http://dx.doi.org/10.1016/j.enpol.2014.10. 009

Valkila, N., \& Saari, A. (2010). Urgent need for new approach to energy policy: the case of Finland. Renew Sustain Energy Rev, (14), 2068-2076. http://dx.doi.org/10.1016/j.rser.2010.03.039

Zhou, X. (2012). History of the development of China's power. Beijing: China Electric Power Press.

\section{Copyrights}

Copyright for this article is retained by the author(s), with first publication rights granted to the journal.

This is an open-access article distributed under the terms and conditions of the Creative Commons Attribution license (http://creativecommons.org/licenses/by/3.0/) 